\title{
Possibility of Microchip Electrophoresis for Biological Application
}

\author{
Masatoshi Kataoka Member (Advanced Industrial Science and Technology, m-kataoka@aist.go.jp) \\ Jun-ichi Kido Non-member (University of Tokushima, kido@dent.tokushima-u.ac.jp) \\ Yasuo Shinohara Member (University of Tokushima, yshinoha@genome.tokushima-u.ac.jp)
}

Keywords : Microchip electrophoresis, Biological application, Endonuclease, Blood Sugar

\section{Introduction}

Miniaturaization of analytical and biological instruments has developed rapidly in the past 10 years. Microchip electrophoresis has recently attracted much attention in DNA analysis due to its high efficiency, high throughput, time-saving ability, easy operation, and low consumption of samples and reagents. Some commercial instruments, such as the Agilent 2100 Bioanalyzer, Shimadzu MCE2010, and Hitachi SV1100 and 1210 , have been developed, which has greatly promoted the further application of microchip electrophoresis. In microchip electrophoresis, nucleic acid fragments are separated by capillary electrophoresis in a chip with microfabricated channels, with automated detection as well as on-line data evaluation. Microfabricated devices are forecast to be fundamental to the postgenome era, especially in the field of genetics and medicine. However, although there are many reports of the use of these instruments to evaluate standard DNA, DNA ladders, PCR products, and commercially available plasmid digests, little information is available about their use with biological materials. It is therefore necessary to evaluate these microfabricated devices for DNA analysis of biological material, for example plasmid DNA isolated from bacteria. In this study, we evaluated the ability of the Hitachi SV1100 to analyze the plasmid DNA,

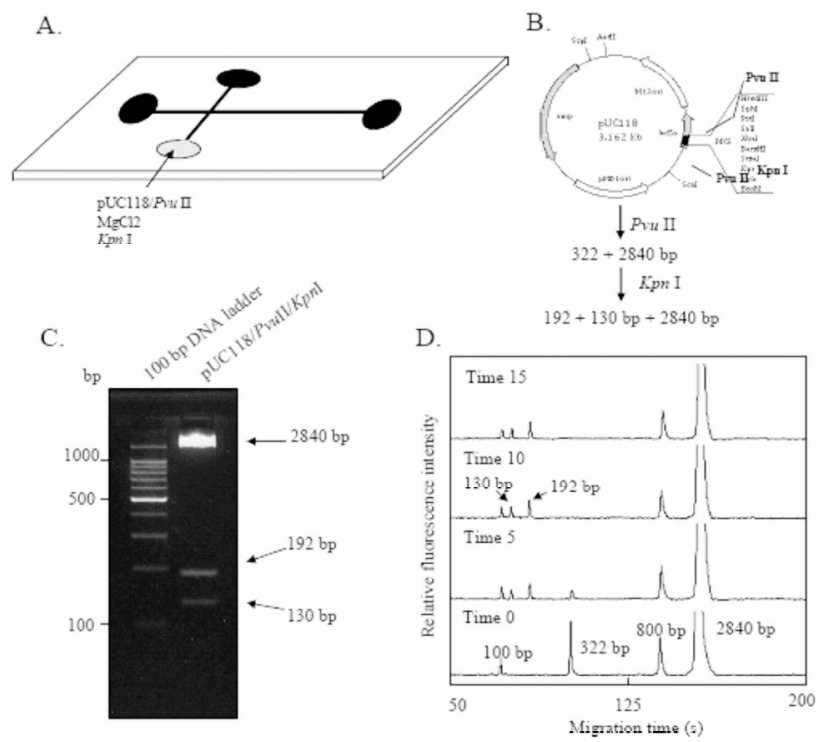

Fig. 1. Sequential analyses of Kpn I digestion of $P v u$ II-digested pUC118 DNA fragments
pUC118 which was isolated from Escherichia coli. And on-microchip endonuclease treatment of pUC118 and sequential analysis were perfromed to examine the feasibility of additional application of DNA analysis. Furtheremore, we evaluate the ability of microchip electrophoresis for determination of blood sugar, and the mitochondrial membrane potential $\left(\Delta \psi_{\mathrm{m}}\right)$.

\section{Experimental Results and Discussion}

To examine the reliability of on-chip endonuclease digest of pUC118, the sample well in Hitachi $i$-chip was used as a reaction chamber (Fig. 1 A). As shown in Fig. 1 D, only 10 min was required for complete DNA digestion, and the accuracy of DNA sizing was also observed, and the high efficiency of microchip electrophoresis for endonuclase analysis was revealed. In medical application, this method will be a powerful tool in clinical diagnosis, for example for analysis of restriction fragment length polymorphism. We also examined the feasibility of the determination of blood sugar derivatized with fluorescent 2-aminoacrydone by microchip electrophoresis with Hitachi SV1100. As shown in Fig. 2, the accuracy in the determination of blood sugar concentration by microchip electrophoresis was compatible with the conventional colorimetric analysis. Furtheremore, we demonstrated the potential of flow cytometry analysis with a microchip for monitoring $\Delta \psi_{\mathrm{m}}$. Changes in $\Delta \psi_{\mathrm{m}}$ may occur during many physiological and pathological processes, and this has attracted particular attention because the mitochondoria are implicated in programmed cell death.

Microchip electrophoresis is being developed predominantly for the sizing and quantification of nucleic acids, proteins and metabolites. In this study, we showed the potential of microchip electrophoresis for another biological applications.

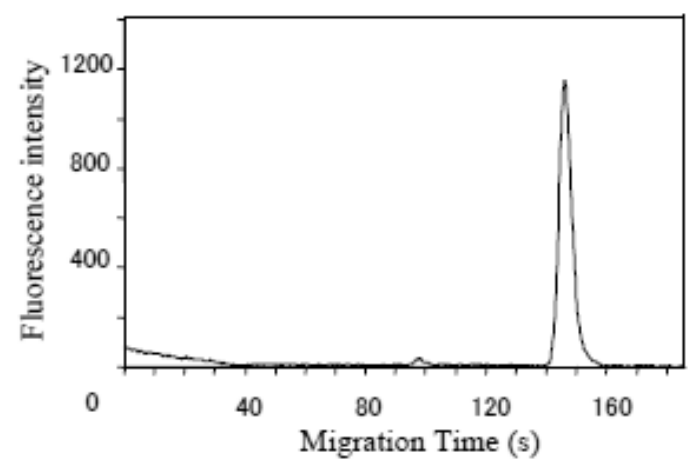

Fig. 2. Determination of blood sugar with the microchip electrophoresis 


\title{
マイクロチップ電気泳動の生物学的解析への応用の可能性
}

\author{
正 員 片岡 正俊* 非会員 木戸 淳一** \\ 正 員 篠原 康雄 $* * *$
}

\author{
Possibility of Microchip Electrophoresis for Biological Application \\ Masatoshi Kataoka*, Member, Jun-ichi Kido**, Non-member, Yasuo Shinohara***, Member
}

Microchip electrophoresis has recently attracted much attention in the field of nuclear acid analysis due to its high efficiency, ease of operation, low consumption of samples and reagents, and relatively low costs. Nucleic acid fragments are separated by capillary electrophoresis in a chip with microfabricated channels, with automated detection as well as on-line data evaluation. Microfabricated devices are forecast to be fundamental to the postgenome era, especially in the field of genetics and medicine. However, although there are many reports of the use of these instruments to evaluate standard DNA, DNA ladders, PCR products, and commercially available plasmid digests, little information is available their use with biological material. In this report, we showed the accuracy of sizing and quantification of endonuclease-digested plasmid DNA. We also showed the feasibility of on-microchip endonuclease treatment of plasmid DNA and sequential analysis as an additional application for DNA analysis. Furthermore, to evaluate the possibility of microchip electrophoresis for biological application, the results of the examination of blood sugar in human plasma and mitochondrial membrane potential were shown.

キーワード：マイクロチップ電気泳動，生物学的解析，制限酵素，血糖

Keywords : Microchip electrophoresis, Biological application, Endonuclease, Blood sugar

\section{1. まえがき}

ヒトゲノムの 30 億塩基対にのぼる全 DNA ヌクレオチド 配列を決定し，その情報の解析を目標として掲げたヒトゲ ノム解析計画が公共研究施設の国際協力により行われ, 2000 年にその概要が，2003 年には全ゲノム配列が発表され た。この情報を応用するためには，膨大な情報を迅速に取 り出すための解析技術と情報処理技術が必要となる。そし て半導体作製技術を応用した超微細加工技術を用いてガラ スやプラスチックなどの基板上にミクロンオーダーの微小 流路を形成することで，そのチャンネル中で電気泳動を行

* 産業技術総合研究所健康工学研究センター生体ナノ計測チー

干761-0395 高松市林町 2217-14

Nano-Bioanalysis Team, Health Technology Research Center, National Institute of Advanced Industrial Science Technology (AIST)

2217-14 Hayashi-cho, Takamatsu 761-0395

** 徳島大学へルスバイオサイエンス研究部歯周歯内治療学分野 干770-8504 徳島市蔵本町 3-18-15

Department of Periodontolgy and Endodontology, Institute of Health Bioscience, The University of Tokushima Graduate School 3-18-15 Kuramoto-cho, Tokushima 770-8504

*** 徳島大学ゲノム機能研究センター遺伝子発現分野

干770-8053 徳島市蔵本町 3-18-15

Division of Gene Expression, Institute for Genome Research, The University of Tokushima

3-18-15 Kuramoto-cho, Tokushima 770-8503
いキャピラリー電気泳動の長所を生かし省サンプル化, 分 析時間の短縮化や高感度な解析が可能なマイクロチップ電 気泳動(Microchip electrophoresis, ME)が DNA 解析に応用さ れている(1)。最近は DNA の解析のみならず RNA，タンパク 質 ${ }^{(2)}$, 糖鎖( ${ }^{(3)}$, 細胞機能解析 ${ }^{(4)}$ などその適用範囲は拡大して きており, さらに装置自体がコンパクト化されること, 操 作も簡単で術者の熟練度の差による解析結果の誤差も少な いため医療や臨床検査などの分野でオンサイト分析への応 用も期待されている。現在ではディスポーザブルなマイク ロチップを用いたマイクロチップ電気泳動装置が数社から 市販され利用可能となっている。本稿では，これらマイク ロチップ電気泳動の基礎的な特徴とともに, 市販されてい るマイクロチップ電気泳動装置を用いた DNA 解析の基本, さらにユーザーの立場からこれらを用いて DNAの制限酵素 処理とその解析，その他の応用例として血糖やミトコンド リア膜電位の測定など生物学的解析への応用性について述 ベたい。

\section{2. マイクロチップ電気泳動の特徵}

〈2·1〉 マイクロチップの構造と検出 マイクロチッ プ電気泳動は, 石英, Polymethyl methacrylate (PMMA), Polydimethylsiloxane (PDMS), ポリカーボネートなどをマイ 


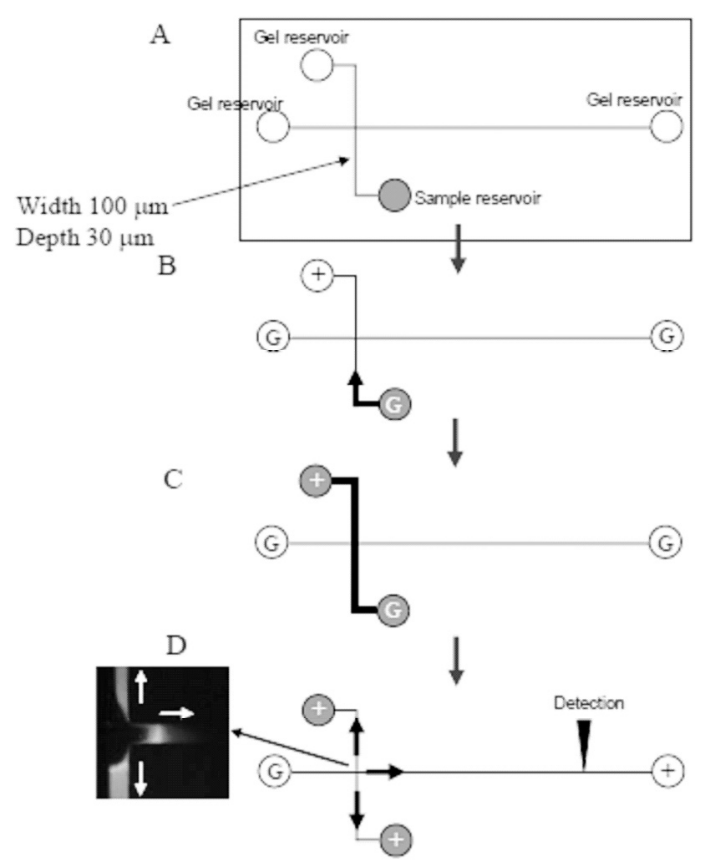

図1 マイクロチップヘの DNA 試料の添加と 分離・解析

Fig. 1. DNA sample application, separation, and its analysis on a microchip.

クロチップの材質として使用した数センチ角のチップ上に 半導体作成技術に基づいた超微細加工技術を用いて，幅 10 $\sim 100 \mu \mathrm{m}$, 深さ 5 50 $\mu \mathrm{m}$ 程度のマイクロチャネルを形成し て，このマイクロチャネル上で電気泳動を行う方法である。 図 1 に基本図を示すが，マイクロチャンネルを十字形に形 成し，ゲルとして分離用支持体をチャンネルに充填後，各 ウェルに順次電荷を印荷することでサンプルの導入・分 離・検出を行う。一枚のマイクロチップ上に複数のマイク ロチャンネルを付与することで, 多数のサンプルを一枚の マイクロチップで同時に電気泳動と解析が可能となり，八 イスループットな解析装置としての利用が可能になる。マ イクロチップ電気泳動による DNA 解析においては, 非架橋 ポリアクリルアミド, セルロース誘導体, ポリエチレンオ キサイドなどのポリマー溶液を分離用支持体として利用す る解析法が主となる。そして解析対象となる DNA サイズに よりさまざまな最適条件が報告されている。メチルセルロ 一スのようなポリマー溶液は, 一定の濃度を超えるとポリ マー分子同士が絡み合い動的ポアを形成する。この場合, 形成されるポアは従来の電気泳動に用いられるゲルのよう に固定されたサイズは有していないが，平均的メッシュサ イズはポリマー濃度に依存する。これを利用することで DNA はポリマー溶液を電気泳動中にゲルの場合と同様に分 子ふるい効果を受けて, 従来のアガロース電気泳動などの ようにその分子サイズに依存して分離される。マイクロチ ヤンネルの形状として $\mathrm{T}$ 型, ダブル $\mathrm{T}$ 型(5), クロス型やダ ブルクロス型(6)等が報告されているが, 本稿ではクロス型チ ヤンネルマイクロチップにおける DNA 試料の分析法を示す
A. Agilent 2100 Bioanalyzer $\quad$ B. Shimadzu MCE-2010 LIF
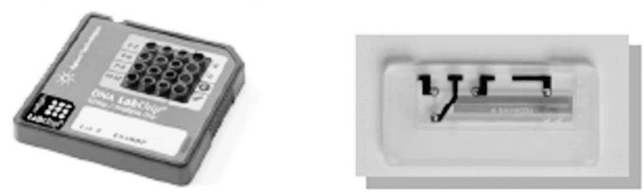

C. 日立SV1100形

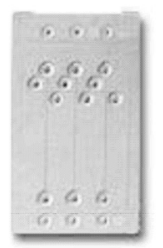

図 2 市販のマイクロチップ

Fig. 2. Commercial microchips.

（図 1)。まずチャンネルと各リザーバーに分離用ゲルとし て利用できるセルロース誘導体などを含む電気泳動用緩衝 液で満たし, サンプルリザーバーにDNA 試料を添加する(図 1A）。その後, 図 1B に図示するように電圧を印加すること により数十秒で試料導入溝は DNA で満たされる（図 1C）。 次に図 $1 \mathrm{D}$ のように分離導入溝と分離泳動溝の交叉部に存 在する DNA 溶液が分離泳動溝に流入してその DNA サイズ に依存して分離される。この際, 試料導入溝ではサンプル リザーバーとゲルリザーバーにも電圧を印加して戻し泳動 を行い, 試料導入溝からの分離泳動溝への余分な試料の流 入を防ぐことが可能となる。分離泳動溝で泳動・分離され た DNA は検出部において, 半導体レーザーや発光ダイオー ドを用いた蛍光検出, さらにUV 検出の方法により検出され る。従来のアガロース電気泳動とエチジュムブロマイド染 色による DNA の検出感度は $1.0 \mathrm{ng} / \mu \mathrm{l}$ 程度であるが, 現在市 販されているマイクロチップ電気泳動装置ではその検出感 度は $0.1 \mathrm{ng} / \mu \mathrm{l}$ と検出感度は高い。そして一回の解析にはピ コリッター単位の DNA 試料が利用されるのみで, 大部分の 試料はサンプルウェルに残ることになる。市販化されてい るマイクロチップ電気泳動装置では, 得られた情報は装置 付属のソフトウェアで解析され泳動パターンの表示, DNA 鎖長の解析や擬似ゲルイメージなどが数分以内に表示され る。

〈2·2〉市販のマイクロチップ電気泳動装置とマイクロ チップ アジレント, 島津製作所や日立化成工業などか らはマイクロチップ電気泳動装置や専用のマイクロチップ が市販化されている。それぞれマイクロチップ電気泳動装 置は, デスクトップ型パソコン大の泳動装置本体と専用の 解析用ソフトウエアを有するノートパソコンで解析を行 う。アジレント社より市販されている Agilent 2100

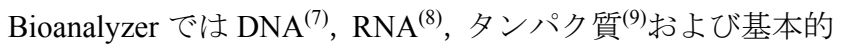
なフローサイトメトリー機能を利用して細胞機能解析 ${ }^{(4)}$ が 可能で, マイクロチップの材質として石英チップが使用さ れている（図 2A）DNA 試料の検出にはレーザー誘起分光 (LIF) 検出が利用されており，30 分で 12 サンプルの同時解 析が可能となっている。島津製マイクロチップ電気泳動装 
A.

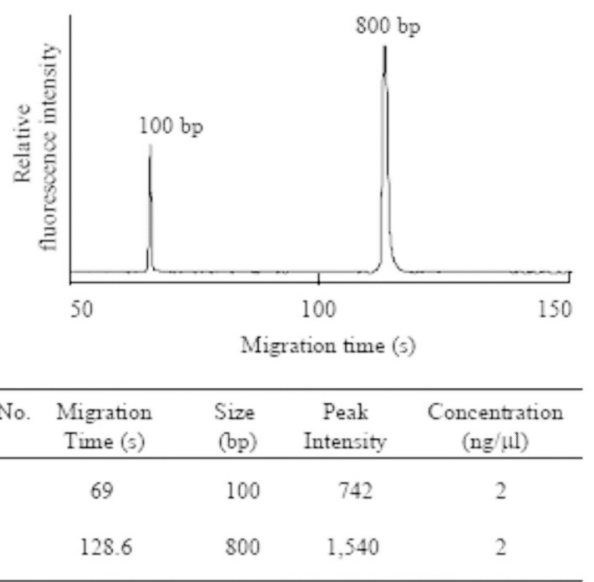

図 3 内部標準 DNA の解析結果

Fig. 3. The data output of the assay of standard DNA on a microchip.

置 MCE-2010 LIF では DNA，RNA，タンパク質の解析が可 能となっている。マイクロチップとしては石英チップが使 用されており (図 2B), 試料 DNA の検出にはレーザー誘起 蛍光法(LIF)が用いられている。さらに試料の導入を含め完 全オートメーション化・自動化がなされており，96 サンプ ルの連続自動解析が可能となっている。日立化成では 3 サ ンプル用（図 2C) と 12 サンプル用のマイクロチップがあり， それぞれ DNA およびRNA の解析が 5 分程度で可能となっ ている。DNA 解析用マイクロチップの材料としては PMMA が使用され，DNA の分離材としては水溶性セルロース誘導 体が用いられており，DNA 検出には蛍光検出が利用されて いる。以下に 3 サンプル解析用の日立 SV1100 形を用いた DNA 解析の結果を示寸。

\section{〈2·3〉 マイクロチップ電気泳動によるDNA 解析の基礎}

日立 SV1100 形を用いた DNA 解析では，各々 $2.0 \mathrm{ng} / \mu 1$ の $100 \mathrm{bp}$ と $800 \mathrm{bp}$ のNA 断片を内部標準として利用すること で, 100 800 bp の範囲で DNA サイズの測定が可能になる。 そこで 100 bp から 800 bp の DNA サイズマーカーの電気泳 動を行い, DNA サイズと移動時間について検討を行った (図 3)。そしてこれら DNA サイズマーカーを用いたマイクロチ ップ電気泳動のエレクトロフェログラムから（図 3A）, $100 \mathrm{bp}$ から $800 \mathrm{bp}$ の DNA 断片は明確に分離されることが確 認できる (図 3B)。これらの市販化されたマイクロチップ電 気泳動装置については, スタンダードな DNA，DNA ラダー や PCR 産物などを用いた DNA 解析が多くなされておりそ の有用性が報告されている(10) (12)。しかしながら一般的な生 物学, 生化学の分野やさらには臨床検查医学の分野で取り 扱われる生物由来の DNA を用いた解析の報告は少ない。そ こで我々は, 大腸菌から分離・精製した一般的な研究室レ ベルで使用される純度のプラスミド DNA，pUC118 を用い た日立 SV1100 形による DNA 解析を行いその信頼性を検討 した ${ }^{(13)} 。 3162$ bp の pUC118 は制限䤉素 $P v u$ II 処理により 2840 bp と 322 bp の 2 つの DNA 断片に切断される。従来の

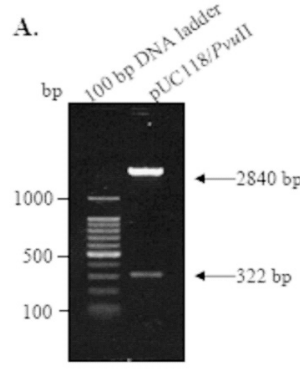

B.

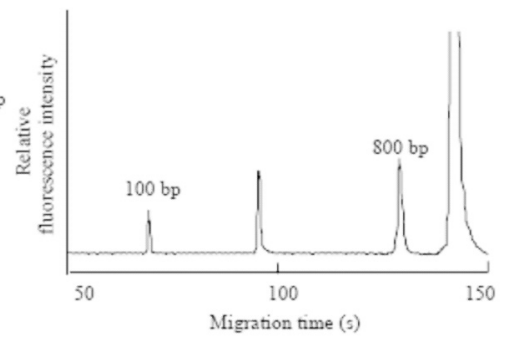

図 4 プラスミド DNA 断片の解析

Fig. 4. Analysis of $P v u$ II-digested pUC118 DNA fragments.

アガロース電気泳動ではDNAサイズは大まかでしか判断さ れず, 電気泳動像だけでは DNA 濃度は判定することはでき ない（図 4A）。マイクロチップ電気泳動から得られるエレ クトロフェログラム（図 4B）では，内部標準である $100 \mathrm{bp}$ と $800 \mathrm{bp}$ の DNA 鎖の他に 2 本のピークが認められ, 解析デ 一タからそれぞれ $320 \mathrm{bp}$ と $1451 \mathrm{bp}$ の DNA 鎖長と判定され た。日立 SV1100 形で DNA 鎖長が測定可能とされる 100〜 800 bp の範囲である 322 bp DNA 断片は 320 bp 鎖長と解析さ れ，わずか $2 \mathrm{bp}$ の誤差しか認めない一方, 測定範囲外とさ れる $2840 \mathrm{bp}$ DNA 断片は $1451 \mathrm{bp}$ と解析されておりサイズ測 定の誤差は大きい。この解析データには既知濃度の内部標 準のピーク強度を基準にして，測定されたそれぞれの DNA 鎖の濃度も表示される。この場合, $20 \mathrm{ng} / \mu 1 \mathrm{pUC} 118$ を制限 䤉素 $P v u$ II で処理しており, 322 bp と 2840 bp のそれぞれの DNA 断片の濃度は約 $2.0 \mathrm{ng} / \mu \mathrm{l}$ と $18 \mathrm{ng} / \mu \mathrm{l}$ になるが，得られ た解析結果からその誤差は $25.5 \%$ と $20.7 \%$ となっている。こ れらの結果, 制限䤉素処理したプラスミド DNA を用いても マイクロチップ電気泳動では正確な DNA サイズの測定が可 能で，さらにある程度の定量性が期待できることが明らか になった。従来のアガロース電気泳動では電気泳動とそれ に引き続くエチジュウムブロマイドによるDNAの染色にそ れぞれ 1 時間程度が必要で, 泳動結果が得られるまで 2 時 間程度が必要であるが，このマイクロチップ電気泳動では 図 $4 \mathrm{C}$ に示寸解析結果が得られるまで電気泳動開始からわず か 10 分以内であり, 高効率・高速な解析が可能であること が明らかになった。

次に DNA 濃度がサイズ測定, 濃度測定にどのような影響 を及ぼすかを検討した。2〜320 ng/ $\mu 1$ のUC118を制限酵素 $P v u$ II で切断しマイクロチップ電気泳動を行った。この場 合, $322 \mathrm{bp}$ の DNA 断片は $0.2 \sim 32.6 \mathrm{ng} / \mu \mathrm{l}$ の濃度に, 一方の $2840 \mathrm{bp}$ の DNA 断片は 1.8 287.4 ng/ $/$ 1 濃度となる。エレ クトロフェログラムから，322 bp DNA 断片は移動時間がほ ぼ一定であるのに対して, 2840 bp DNA 断片は DNA 濃度が 上昇するのに従い移動時間が短くなる結果が得られた。そ して 100 800 bp の測定範囲内では DNA 断片のサイズ測定 の正確性が認められたが, 高濃度になるに従いその定量性 は低下した。このマイクロチップ電気泳動装置で測定範囲 外とされる 2840 bp DNA 断片は濃度に依存して移動時間の 
短縮が認められそのDNAサイズは短く見積もられるように なる。従来のアガロース電気泳動でDNAの分離を行う場合, あらかじめアガロースにエチジュウムブロマイドを加えて 電気泳動を行うと，DNA 量が多い場合には分子量の大きい DNA 断片はその移動速度が相対的に速くなる現象が知られ ている。このマイクロチップ電気泳動では, あらかじめ分 離用ゲルと使用する泳動用緩衝液にはエチジュウムブロマ イドが含まれており, このためアガロース電気泳動と同様 の現象が認められると考えられる。

\section{3. マイクロチップ電気泳動の生物学的解析への 応用}

前述のようにマイクロチップ電気泳動による DNA 解析 は, 従来のアガロース電気泳動に比べ高速・高感度・省サ ンプルな解析が可能となっておりその利用価值は非常に高 い。そしてさらにその特徵を生かして, 分子生物学の分野 での利用価值を高めることが可能かどうか応用性・発展性 について検証した。pUC118 をはじめプラスミドDNA は分 子生物学などの分野で最も一般的に使用されているべクタ 一であるが，これらプラスミド DNA を制限酵素処理で切断 することは生物学や分子生物学等の分野では日常最も頻繁 に行われる操作の一つと言っても過言ではない。従来, こ の制限酵素処理にはマイクログラム単位のDNA を酵素反応 のために一時間以上処理し, さらにアガロース電気泳動と 染色を行って，DNA の切断を確認している。そこで制限酵 素処理をマイクロチップのサンプルウェルで直接行い, 引 き続きマイクロチップ電気泳動を行うことで高速・高感度 な解析が可能かどうか検討した ${ }^{(13)}$ 。また最近, PMMA 基板 を用いたマイクロチップ電気泳動を用いて単糖の分離・解 析が報告されている(14)。その他, その応用性を確認するた めヒト血液を用いて血糖值の測定が可能かどうかも検討し ており,その結果も紹介したい。さらに, これら電気泳動 による分離・解析のみならず, マイクロチップを用いるこ とでミトコンドリア膜電位の測定など, 細胞機能の解析に 応用できることを明らかにしている(4)。

〈3.1〉 DNA 制限酵素処理とその解析 マイクロチッ プ上で直接 DNAの制限酵素処理とその解析への応用の可能 性について検討するため, サンプルウェルを酵素反応の場 として利用し解析を行った。図 5 に示すようにサンプルウ エルには $10 \mu 1$ の溶液を加えることが可能であり，そこでプ スミド pUC118 と制限酵素活性に不可欠な $\mathrm{MgCl}_{2}$, そして制 限酵素 Kpn I $1.0 \mu \mathrm{l}$ と内部標準を計 $10 \mu \mathrm{l}$ としてウェルに添 加した（図 5A）。このマイクロチップを電気泳動装置にセ ットして, そのまま室温にて酵素処理と電気泳動による解 析を行った。DNA として制限酵素 $P v u$ II で切断済みの pUC118 を用いているが, $P v u$ II と Kpn I の二重消化で 130, 192 および 2840 bp の 3 個の DNA に切断される (図 5B)。 アガロース電気泳動では分子量マーカーから各切断断片の 大まかなサイズは推定されるが正確には判定できない（図 5C)。ところでマイクロチップ電気泳動では, 一回の解析で

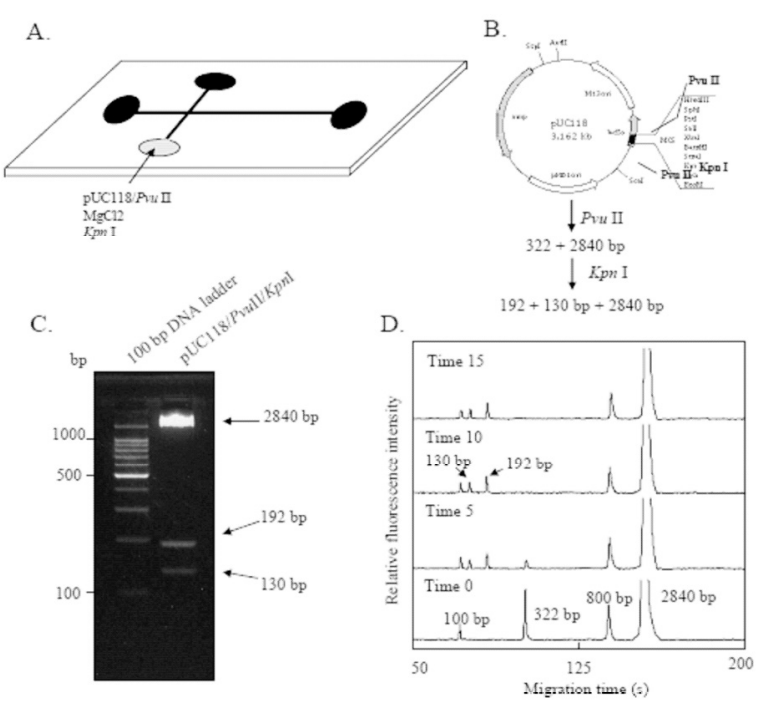

図 5 チップ上での制限酵素処理と解析

Fig. 5. Sequential analyses of Kpn I digestion of $P v u$ II-digested pUC118 DNA fragments.

分離泳動溝に流れる試料はピコリットルオーダーであり, ほとんどの試料溶液はサンプルウェルに残ることになる。 そこで図 5A の条件で, チップをそのまま電気泳動装置本体 にセットしたまま $0,5,10,15$ 分後に電気泳動のスタートボ タンを押すだけで系時的に解析を行った。図 5Dにそのエレ クトロフェログラムを示す。0 分では内部標準の 100 bp と $800 \mathrm{bp}$ 間に pUC118 Pvu II 断片である 322 bp DNA 断片と, それ以外の $2840 \mathrm{bp}$ に相当するピークを認める。5 分後には 大部分の 322 bp DNA が Kpn I で消化されており, 130 bp と 192 bp DNA に相当する 2 本のピークが観察され, 10 分後に は 322 bp DNA は完全に消化されることが認められた。解析 データから, 10 分後では 130 bp と 192 bp DNA は各々 127 bp

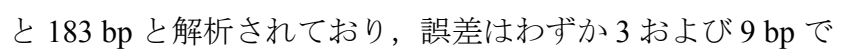
あった。定量性においては，それぞれ $40 \%$ と $37 \%$ の誤差が 認められたが, 酵素処理開始後 20 分以内でこれらの解析結 果を得ることができた。以上のようにマイクロチップのサ ンプルウェルを酵素反応の場と利用することで, 直接 DNA を制限酵素処理し引き続き系時的に電気泳動を行うことで ほぼリアルタイムに DNA の消化を確認することができる。 これらの特長を生かすことで, 制限酵素の kinetic analysis や ジーンバンク作成時の DNA 切断への応用が可能となる。さ らに医療の分野ではハイスループットな制限酵素切断断片 長多型の診断が容易になると考えられる。

〈3·2〉 その他の応用性について マイクロチチップ 電気泳動では核酸やタンパク質の他, グルコースをはじめ とする単糖の解析についても報告されている(14)。そして 我々はヒトプラズマを用いて, 2-aminoacridone (AMAC)で血 糖を蛍光標識して標準グルコースを対照とすることで，マ イクロチップ電気泳動により血糖值の迅速な測定が可能で あることを確認している（図 6）。また基本的なフローサイ トメトリー機能を有する Agilent bioanalyzer 2100 を用いるこ 


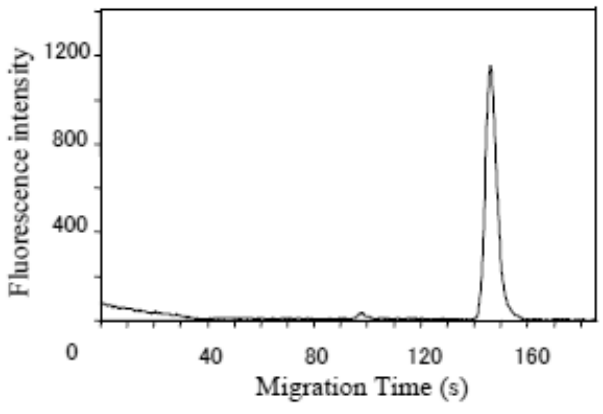

図 6 血糖值の測定

Fig. 6. Determination of blood sugar with the microchip electrophoresis.

とで，ミトコンドリア膜電位の測定が可能であることを報 告している(4)。ミトコンドリアは細胞のエネルギー産生機関 としてだけでなくアポトーシスにも深く関与することが知 られており, 細胞にアポトーシスシグナルが加わるとミト コンドリア膜電位の喪失などの透過性遷移が起こり細胞質 へのチトクロム $\mathrm{c}$ 漏出を介して細胞死にいたることが知ら れている。さらに臨床面ではミトコンドリア病などのミト コンドリア機能異常を有する疾患では，ミトコンドリア膜 電位を測定することで確定診断を行っている。従来は膜電 位の測定にはFACS などを用いていたが, 測定には大量の細 胞が必要なこと, 機器が高価でありそしてその操作には熟 練さが要求されるなどの欠点があった。一方，マイクロチ ップを用いることで, FACS に比較して必要な細胞量は 1/10 以下, 廉価で操作が簡単という特徵があり, 今後は臨床診 断の面でも注目されるものと予想される。

これらの結果を踏まえ, マイクロチップ電気泳動は DNA を中心とする核酸の解析のみならず, 酵素反応の解析やそ の他, 血糖をはじめとする臨床診断マーカーなどその応用 範囲は大きいと考えられ，今後益々その適応範囲は拡大寸 るものと考えられる。

(平成 18 年 5 月 25 日受付)

\section{文献}

(1) L. Zhang, F. Dang, and Y. Baba : "Microchip electrophoresis-based separation of DNA", J Pharm Biomed Anal, Vol.30, No.6, p.1645-1654 (2003)

(2) M. Tabuchi, Y. Kuramitsu, K. Nakamura, and Y. Baba : "A 15-s protein separation employing hydrodynamic force on a microchip", Anal Chem, Vol.75, No.15, pp.3799-3805 (2003)

( 3 ) F. Dang, L. Zhang, M. Jabasini, N. Kaji, and Y. Baba : "Characterization of electrophoretic behavior of sugar isomers by microchip electrophoresis coupled with videomicroscopy", Anal Chem, Vol.75, No.10, pp.2433-2439 (2003)

(4) M. Kataoka, Y. Fukura, Y. Shinohara, and Y. Baba : "Analysis of mitochondrial membrane potential in the cells by microchip flow cytometry", Electrophoresis, Vol.26, No.15, pp.3025-3031 (2005)

( 5 ) L. B. Koutney, D. Schmalzing, T. A. Taylor, and M. Fuchs : "Microchip electrophoretic immunoassay for serum cortisol", Anal Chem, Vol.68, No.1, pp.18-22 (1996)

(6) L. M. Fu, R. J. Yang, and G. B. Lee : "Electrokinetic focusing injection methods on microfluidic devices", Anal Chem, Vol.75, No.8, pp.1905-1910 (2003)

( 7 ) N. J. Panaro, P. K. Yuen, T. Sakazume, P. Fortina, L. J. Kricka, and P. Wilding : "Evaluation of DNA fragment sizing and quantification by the agilent 2100 bioanalyzer", Clin Chem, Vol.46, No.11, pp.1851-1853 (2000)

( 8 ) C. L. Miller, S. Diglisic, F. Leister, M. Webster, and R. H. Yolken : "Evaluating RNA status for RT-PCR in extracts of postmortem human brain tissue", Biotechniques, Vol.36, No.4, pp.628-633 (2004)

(9) R. Ohashi, J. M. Otero, A. Chwistek, and J. F. P. Hamel : "Determination of monoclonal antibody production in cell culture using novel microfluidic and traditional assays", Electrophoresis, Vol.23, No.20, pp.3623-3629 (2002)

(10) L. Zhang, F. Dang, and Y. Baba : "Stepwise gradient of linear polymer matrices in microchip electrophoresis for high-resolution separation of DNA", Electrophoresis, Vol.23, No.14, pp.2341-2346 (2002)

(11) F. Xu, J. F. abasini, and Y. Baba : "DNA separation by microchip electrophoresis using low-viscosity hydroxypropylmethylcellulose-50 solutions enhanced by polyhydroxy compounds", Electrophoresis, Vol.23, No.20, pp.3608-3614 (2002)

(12) L. Ding, K. Williams, W. Ausserer, L. Bousse, and R. Dubrow : "Analysis of plasmid samples on a microchip", Anal Biochem, Vol.271, No.11, pp.2241-2247 (2004)

(13) M. Kataoka, S. Inoue, K. Kajimoto, Y. Shinohara, and Y. Baba: "Usefulness of microchip electrophoresis for reliable analyses of nonstandard DNA samples and subsequent on-chip enzymatic digestion", Eur J Biochem, Vol.271, No.11, pp.2241-2247 (2004)

(14) E. Maeda, K. Hirano, Y. Baba, H. Nagata, and M. Tabuchi : "Conformational separation of monosaccharides of glycoproteins labeled with 2-aminoacrydone using microchip electrophoresis", Electrophoresis, Vol.27, No.10, pp.2002-2010 (2006)

片 岡 正 俊

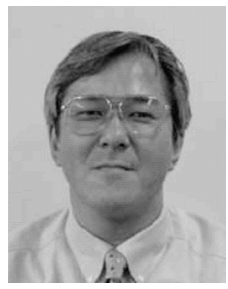

木 戸 淳一

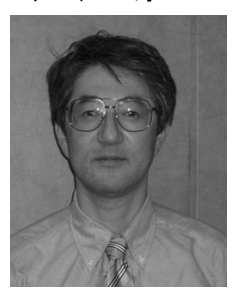

（非会員） 1957 年 10 月 31 日生。1983 年徳島 大学歯学部卒, 1987 年徳島大学大学院歯学研究 科修了。徳島大学歯学部助手, 同附属病院講師, 同歯学部助教授を経て 2004 年より徳島大学大 学院ヘルスバイオサイエンス研究部助教授。専 門はバイオマーカーを用いた歯周病診断。歯学 博士。

篠 原 康 雄

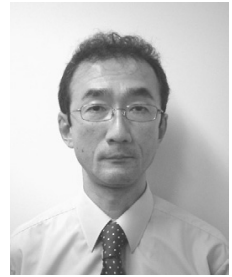

（正員） 1962 年 2 月 16 日生。1986 年徳島大 学歯学部卒業, 1990 年徳島大学大学院歯学研究 科修了。徳島大学歯学部助手, ゲノム機能研究 センター助教授を経て 2006 年産術研健康工学 センター主任研究員。薬物誘発性歯肉増殖症の 発症機構とナノバイオデバイスの研究に従事。 歯学博士。 